\title{
The Marquis de Condorcet goes to Bern
}

Bochsler, D

\begin{abstract}
Condorcet cycles' (or 'paradoxes of cyclical majorities') are an empirically rare phenomenon. A referendum in the Swiss canton of Bern on 28 November 2004 presents a rare occurrence. This study presents a new multi-option referendum procedure that makes Condorcet cycles visible, and it argues that in this case, the paradox might have resulted from strategic voting patterns.
\end{abstract}

DOI: https://doi.org/10.1007/s11127-009-9507-y

Posted at the Zurich Open Repository and Archive, University of Zurich

ZORA URL: https://doi.org/10.5167/uzh-48554

Journal Article

Published Version

Originally published at:

Bochsler, D (2010). The Marquis de Condorcet goes to Bern. Public Choice, 144(1-2):119-131.

DOI: https://doi.org/10.1007/s11127-009-9507-y 


\title{
The Marquis de Condorcet goes to Bern
}

\author{
Daniel Bochsler
}

Received: 4 March 2008 / Accepted: 28 August 2009 / Published online: 19 September 2009

(C) Springer Science+Business Media, LLC 2009

\begin{abstract}
Condorcet cycles' (or 'paradoxes of cyclical majorities') are an empirically rare phenomenon. A referendum in the Swiss canton of Bern on 28 November 2004 presents a rare occurrence. This study presents a new multi-option referendum procedure that makes Condorcet cycles visible, and it argues that in this case, the paradox might have resulted from strategic voting patterns.
\end{abstract}

Keywords Condorcet cycle $\cdot$ Strategic voting $\cdot$ Referendum $\cdot$ Swiss cantons

\section{Introduction}

A Condorcet cycle, or cyclical majority, is defined as a situation where a group of voters is called upon to decide between three (or more) alternatives. From several individual transitive preference orders, a collective intransitive preference order takes shape. Such paradoxes are vividly discussed in the public choice literature (Black 1958; Sen 1970; Gehrlein 2006, and many others), but empirical instances are actually quite difficult to find. Most voting procedures do not record individual voters' full preference orders (Nurmi 1998, 1999: 25; Gehrlein 2006: 33). Multi-option referendums, which have recently become more widespread in Swiss cantons, represent one procedure where voters actually do express a full order of their preferences over three options - and where the collective preference order is therefore visible in the results. This study explains the mechanism of the constructive referendum, the multi-option referendum practiced in several Swiss cantons, and documents the occurrence of a majority cycle in a 2004 referendum vote in the canton of Bern.

The Bernese Condorcet cycle differs from other Condorcet cycle instances in two key factors. First, it provides a record of voters' full preference orders. Most empirical studies of Condorcet cycles have not involved real decisions, and have instead relied upon polled or

D. Bochsler ( $₫)$

Center for Comparative and International Studies, Universität Zürich, Seilergraben 53, 8001 Zürich,

Switzerland

e-mail: bochsler@ipz.uzh.ch

url: www.bochsler.eu 
assumed voter preferences. Second, I argue that in the case of the Bernese Condorcet cycle, the sincere preferences of the voters were dominated by a single issue dimension-a case where one might have expected single-peakedness of the voter's preferences. The cyclic majority was probably a product of strategic voting.

Condorcet cycles can arise when three or more decision makers are voting on three or more mutually exclusive options. This includes elections of representatives, decisions in referendums, decisions of governments, committees or parliaments, as well as any other collective choice. If one of the options beats out another option in a pair-wise comparisonearning a majority of the vote-then a Condorcet winner can be identified. If no Condorcet winner is apparent, then different decision rules, or the order in which options are presented to the voters, may lead to different results (see Riker 1986; Saari 2001: 91-93). Usually, committees or parliaments employ the amendment procedure for multi-option decisions. If there is more than one option for an amendment, then the proposed amendments are voted on in pairs, leading to the elimination of the losing amendment. The procedure is repeated until there is only one amendment left, and this winning proposal is then pitted against the status quo. In the case of Condorcet cycles, the status quo always wins under this procedure, because it enters the procedure last (Black 1958; Gehrlein 2006: 32; Riker 1986: 10-17), except if voters vote strategically. Since the amendment procedure does not rely on a full pair-wise comparison of all options, it cannot yield information on full preference orders, and thus cannot effectively detect Condorcet cycles. (To do this, we must gather additional information about the individual preference orders of the decision makers.) The constructive referendum, by contrast, which will be discussed below, differs in both aspects. It provides us with full information about the collective preference order. And it is reform-friendly: supporting a reform option that wins a greater share of individual preferences than the status quo.

The first part of this paper explains the nature of Condorcet cycles, and briefly discusses the relevant empirical literature on the subject. Subsequently, I move to discuss how the Swiss practice of constructive referendums differs from other situations of multi-option decision making, before explaining the Condorcet cycle that occurred in Bern. While data do not allow us to study the voting behavior of individuals, I use results from the 389 municipalities - mainly transitive - to show that the aggregation of fully transitive preference orders at the municipal level led to a majority cycle at the cantonal level.

\section{Previous research}

Consider a situation with three discrete decision options- $a, b, c$-and three voters- 1 , 2 , 3. Suppose voter 1 has the preference order $a>b>c$, voter 2 the order $b>c>a$, and voter 3 the order $c>a>b$. The aggregation of these three preference orders results in a majority (voters 1 and 3 ) that favors $a$ over $b$. A majority of the voters (1 and 2) also favor $b$ over $c$, but nevertheless, a majority (voters 2,3) favor $c$ over $a$. This result represents a cyclic majority, or a Condorcet cycle, and there is no option that would win against any other option if they were compared pair-wise. While each of the individual votes is fully transitive, the sum of these votes proves to be intransitive.

This paradox, and possible solutions to it, have fascinated many scholars, and have been discussed widely in the public choice literature (Black 1958; Sen 1970; Gehrlein and Fishburn 1976; Riker 1982; Saari 2001, and many others). The broader field, which centers on the stability of majority decision-making, has been described by Green and Shapiro (1994: 113) as one "that reflects the imbalance between theory and empirical research". Empirically, very few instances of fully documented Condorcet cycles have been identified. Many 
empirical studies that rely on full information about voters' preference orders, about multioption decisions that resulted in the selection of one candidate or option, did not provide any evidence of a Condorcet paradox (for instance, Chamberlin et al. 1984; Feld and Grofman 1988, 1992; Tullock 1981).

Often, the Condorcet cycles described in empirical work rely on assumed or polled preference orders, instead of real voting results (Riker 1958, 1982; Lagerspetz 1997; Gaubatz 1995; Kurrild-Klitgaard 2001, to name a few; see Gehrlein 2006: Chap. 2, for an overview). Mackie (2003) has been a particularly vocal critic-suggesting that many of these assumptions do not hold, and that the empirical evidence is weak. Grofman (2004: 36-37) argues that most of the existing research relies on the impartial culture assumption (assuming a not connected random probability of each preference order), or on closely related distributions, which are empirically implausible.

There are several theoretical reasons that explain why Condorcet cycles might be rare. Black (1958) has shown that when voters have single-peaked preference orders (meaning that decisions are taken along a single-dimensional issue dimension), Condorcet cycles do not emerge. In addition, it has been shown that they can be prevented through logrolling (Tullock 1981). However, there is scant evidence that the opposite effect may be true as well, and strategic voting or strategic amendments can be used to cause cyclical majorities intentionally, in order to affect the outcome of a vote (Riker 1958; Senti 1998, among others). ${ }^{1}$ Well-established decision-making processes in consolidated political systems might prevent the emergence of Condorcet cycles (cf. Shepsle 1979; Andrews 2002). Hence, it is not surprising that cycling is rare in established democracies, and that cycling majorities occur most often in countries with a weak institutional order, a weak governing majority, and in the absence of a dominant, one-dimensional conflict.

Even if Condorcet cycles were present in the preferences of an electorate, they remain difficult to detect in most voting situations. The voting procedures used to select one out of several mutually exclusive options generally do not allow voters to fully express their preference order (Gehrlein 2006: 33). Because of this, we usually lack information that would help directly to establish possible Condorcet cycles, and must rely on additional information to reveal them. A number of empirical studies on the occurrence of cyclic majorities are not based on voting results, but rely instead on the preference rankings expressed in opinion polls (such as Van Deemen and Vergunst 1998; Kurrild-Klitgaard 2001; see as well Gehrlein 2006, Chap. 2). Usually, these studies do not involve any questions that were decided by majority vote, but rather decisions made under proportional representation (PR), or multi-option choices that were not subject to real decisions. Under PR, a Condorcet paradox has no consequences whatsoever on the electoral outcome; therefore, these cases do not seem as relevant as cycles that occur in majoritarian voting institutions. Kurrild-Klitgaard (2008) has argued that survey data of large electorates would allow for the detection of many more Condorcet cycles than commonly are found, if it considered margins of errors in electoral surveys. In contrast, Feld and Grofman (1992) employed results under the Single Transferable Vote (which requires preference ordering through the voters), but did not find any Condorcet cycles.

Other have relied on assumed-rather than measured-preference orders of electors (Lagerspetz 1997). In addition, a number of researchers have employed simulations based

\footnotetext{
${ }^{1}$ In decisions with several options, actors might strategically support a killer amendment in order to eliminate a compromise option and ensure that their most-favored option will win (see also Jenkins and Munger 2003). The applicability of this strategy depends on the voting procedure.

In a different vein: strategic amendments might also help to result in Condorcet paradoxes, and change the outcome of a decision (Riker 1958).
} 
on the assumption of impartial culture in order to estimate the probability of encountering a cycling majority. Jones et al. (1995), Van Deemen (1999) and Regenwetter et al. (2006: 50) show that, under the disputed assumption of impartial culture (each voter preference is equally likely), and for large samples of voters, Condorcet cycles are extremely rare.

\section{Referendums with several alternatives in the Swiss constitutional practice}

Voting procedures figure strongly in whether Condorcet paradoxes are visible or not; cyclical majorities might occur often-but they can be detected only if there is information about the full ordering of preferences over several options. Voting systems rarely give us such information. Indeed, most decisions are made by simple binary (yes/no) votes. ${ }^{2}$ In the case of multi-option referendums or votes, voting systems typically follow the amendment procedure or another procedure that does not include a full ranking of the options or a full pair-wise comparison of any two options.

Switzerland demonstrates the most frequent use of direct democratic instruments, including initiatives and referendums, and does so at all levels of administration: the national level, in the 26 cantons, and in the almost 3000 municipalities. The procedures of direct democracy are subject to cantonal legislation: certain cantons automatically submit amendments of cantonal laws to mandatory referendums; others in the same cases foresee only an optional referendum, asked for by a certain number of voters (see Lutz and Strohmann 1998 for an overview). In the canton of Bern, legal amendments are voted on if 10,000 voters (out of some 700,000) demand it. As a pioneering canton, Bern introduced a new form of a referendum in 1993: the constructive referendum, under the name "referendum with people's amendment" (Referendum mit Volksvorschlag). Instead of being limited to opposing new laws or legal amendments, committees can now propose their own alternative formulation of a law. Subsequently, the voters can chose between three options on their ballot: the one formulated by the parliament, the one by the referendum committee, and the status quo.

The introduction of this new option has been accompanied by another important change to the voting procedure for three-option referendums. On the ballots, both of the reform options are separately set in opposition to the status quo. An additional question asks for the voters' preference between both reform options. If either of both reform options tops the status quo, it wins. If both reforms are favored over the status quo, the reform option that beats the other proposal (Condorcet winner) will be enacted. The same procedure applies if there are two or more people's proposals, resulting in four or more options. ${ }^{3}$ Different

\footnotetext{
${ }^{2}$ Rather than directly opposing several reform projects, some democracies present several inter-connected reform projects to the voters on the same day or on subsequent ballots. These are not connected to the same referendum question, however, and voters decide these issues separately. Brams et al. (1998) warn that this procedure does not allow for an adequate representation of preferences, since decisions on several dimensions of the vote might rely on each other. Higley and McAllister (2002) discuss a rare case of a multi-option referendum in Australia.

${ }^{3}$ If three or more reform options gain a majority of votes over the status quo, then optional questions about the reform proposals decide which proposal is accepted. The winner is the one that wins a majority of votes over the other proposals in most of the optional questions. If several proposals win in the same number of optional questions (in the case of a Condorcet cycle), the one with the highest number of votes in the optional questions is accepted (Gesetz über die politischen Rechte, amendment of 1994, Art. 59e).

In one possible case, the constitution of 1993 (article 63) restricts the possibility of an optional referendum to three options. This is the case if the parliament submits two options of a law to the referendum. Here, an additional people's proposal would not be allowed. However, it is unclear what happens in the case of several people's proposals.
} 
from other frequently practiced procedures of optional voting, this procedure is more likely to lead to reforms when majority cycles occur. The usually employed amendment procedure opts for the status quo in the case of majority cycles.

In the period since Bern first instituted the constructive referendum, two more Swiss cantons (Zurich and Nidwalden) have followed. In the other cantons and at the national level, the constructive referendum remains unavailable as a means of decision-making.

The referendum-with-people's-amendment has substantially increased the number of multi-option referendums. This can be traced to two main reasons. Before the new procedure was introduced, the possibility of multi-option votes had been restricted to occasions where the parliament opted for such a procedure. Essentially, it was used only rarely-when the parliament decided to counter a popular initiative (a new law proposed by a committee of voters) with its own counterproposal.

Second, the new rules for multi-option referendums often give one of the reform options a real chance to pass. Previously, multi-option referendum rules were unfavorable to reforms. Voters could express only one preference-promoting either the status quo or one of the two reform options. Only if one of the reform projects won an absolute majority of the valid votes (which is rare, especially in a situation with a counterproposal that favors changes similar to the people's initiative), could it be approved. ${ }^{4}$ Because of this, any parliamentary counter-proposals to popular initiatives (which typically contain a part of the committee's claims), usually motivate initiative committees to withdraw their bill. (This is done in order to avoid a foreseeable defeat at the polls, and to increase the chances that at least the counterproposal might win.) At the national level, only a few examples of popular votes with several alternatives have occurred, and only after a change in the voting procedure in 1987.

By law, referendum questions in Switzerland are required to address a single issue. They are not allowed to combine questions from unconnected policy fields. This prevents referendums on heterogeneous packages of laws, which might deviate importantly from singlepeakedness and subsequently favor cycling majorities. The next section will explain the aims of the new voting procedure in detail, referring to the example of the optional vote of 28 November 2004 in the canton of Bern.

\section{The Condorcet cycle of the 28 November 2004}

On 28 November 2004, the canton of Bern held a referendum vote on a revision of the law on state employees. Two alternative amendments were presented in opposition to the status quo: the proposal of the cantonal parliament, and the "people's amendment", which was proposed by a referendum committee. According to the voting procedure in the canton of Bern, which follows from the new national rules, voters were asked three questions: first, they were asked whether they preferred the parliamentary proposal over the status quo (Yes/No vote). In the second question, they were asked for their preference on the people's amendment (Yes/No). And third, they were asked which of the two reforms (the parliamentary one or the people's proposal) they favored (see Fig. 1).

The decision-making procedure was stated on the ballot paper: Every reform proposal that won a majority of the votes over the status quo would be accepted. If both reform proposals won a majority of Yes-votes (if both are favored over the status quo), then the third question (regarding which reform was favored) would decide which of the two reform proposals would become law.

\footnotetext{
${ }^{4}$ At the national level, the procedure was abolished in 1987; see Linder (1999: 249).
} 


\section{Stimmzettel für die kantonale Volksabstimmung vom 28. November 2004}

\section{Bulletin de vote pour la votation cantonale du 28 novembre 2004}

\section{Änderung des Gesetzes über das öffentliche Dienstrecht (Personalgesetz) Loi sur le statut général de la fonction publique (Loi sur le personnel) (Modification)}

1 Wollen Sie die Vorlage des Grossen Rates annehmen?

Acceptez-vous le projet du Grand Conseil?

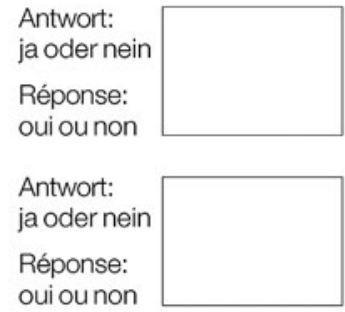

2 Wollen Sie den Volksvorschlag annehmen?

Acceptez-vous le projet populaire? oui ou non

Die Fragen 1 und 2 können je mit "Ja» oder «Nein» beantwortet werden. Vous pouvez répondre aux questions 1 et 2 par «oui» ou par «non».

\section{Stichfrage}

Für den Fall, dass sowohl die Vorlage des Grossen Rates als auch der Volksvorschlag angenommen werden.

\section{Question subsidiaire}

Si les deux projets sont acceptés.

3 Soll die Vorlage des Grossen

Rates (Vorlage GR) oder der Volksvorschlag in Kraft treten?

Lequel de ces deux textes doit entrer en vigueur, le projet du Grand Conseil (projet GC) ou le projet populaire?

\section{Zutreffendes ankreuzen Mettre une croix dans la case qui convient}

so/ainsi:

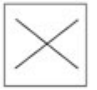

Vorlage GR

Volksvorschlag Projet GC Projet populaire
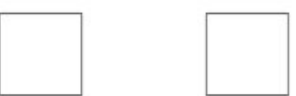

Bei Frage 3 darf nur ein Feld angekreuzt werden; sonst gilt die Frage als nicht beantwortet.

Quant à la question 3 veuillez cocher une seule case, car sinon, la réponse est réputée non valable.

Vom Stimmausschuss auf der Rückseite abstempeln lassen

Veuillez faire timbrer au verso par le bureau électoral

Fig. 1 The official ballot paper. Source: Chancellery of the canton

The outcome of the vote of 28 November 2004 was perceived as irrational by the public, in that the amendment of the parliament obtained a majority of votes over the status quo, 
Table 1 Referendum result, 28 November 2004, Swiss canton of Bern. Source: Chancellery of the canton

\begin{tabular}{llrr}
\hline & Yes & No & Empty \\
\hline $\begin{array}{l}\text { Amendment of the parliament (opposed to the } \\
\text { status quo) }\end{array}$ & $109.812(51.6 \%)$ & $102.796(48.4 \%)$ & 13.150 \\
$\begin{array}{l}\text { People's amendment (opposed to the } \\
\text { status quo) }\end{array}$ & $104.144(49.4 \%)$ & $106.832(50.6 \%)$ & 14.782 \\
$\begin{array}{l}\text { Amendment of the parliament (opposed to } \\
\text { the people's amendment) }\end{array}$ & $101.586(48.9 \%)$ & $106.863(51.1 \%)$ & 18.109 \\
\begin{tabular}{l} 
Turnout: $32.8 \%$ \\
\hline
\end{tabular} & & & \\
\end{tabular}

while the people's amendment did not (Wyler 2004, 2005). Nevertheless, a majority of voters favored the people's amendment over the amendment of the parliament (Table 1). According to the voting rules, the reform of the parliament was accepted, even though a majority of voters would have favored the people's amendment over the parliamentary one. In short, the optional referendum of November 2004 resulted in a cycling majority.

\section{The content of the proposals}

The referendum in question involved a reform project aimed at changing the system by which state employees' salaries were increased. While the amount of money proposed for salary increases was equal across the status quo and both reform projects, the proposed mechanism of increase differed substantially. Under the status quo (SQ), there was an automatic yearly salary increase for all employees. The parliament, however, wanted to abandon any automatism, and introduce a shift towards a performance-based system (parliamentary proposal, "GR"). While right-wing parties and private employer organizations supported the reform, it was opposed by the left-wing parties in parliament, and by the labor unions. The opponents proposed a mixed model, which was a compromise between the parliamentary proposal and the status quo. It would have cut the automatic increase of the employees' salaries to half; the other half of the money would have been distributed based on the employees' performance, according the parliamentary proposal. In other words, the opponents proposed a reform (people's amendment, "VV") which would go in the same direction as the parliamentary proposal—but going only half as far as the parliamentary reform. Opponents of this plan argued that the parliamentary proposal would place low-paid employees at a disadvantage, since these workers usually suffer when performance-based indicators are applied. Table 2 gives an overview over the voting recommendations by the political parties and associations.

\section{Reconstructing the majority cycle from municipal voting results}

In the press, the contradictory aggregated result was perceived as a proof of voter confusion over referendums with several alternatives. It was suggested that some voters filled in the referendum ballot in an intransitive and thus irrational way. Referendum results are available only at the aggregated level (by municipalities), and there is no information about the individual ballots - therefore, we cannot establish how many ballots were cast with intransitive preference order. While it is impossible to disaggregate the result-and to ascertain 
Table 2 Official recommendations of political parties and associations for the vote

Recommendation GR $>$ SQ $>$ VV Parties: SVP, FDP, EDU, CVP, JF ${ }^{\mathrm{a}}$ (all right wing parties)

Associations: Handels- und Industrieverein HIV [trade and industry association], Berner KMU [small businesses], Arbeitgeberverband [private employers association]

Reccomendation VV > SQ > GR Parties: SP, EVP, GB, GFL (all left wing parties)

Associations: Gewerkschaftsbund [trade unions],

Staatspersonal-BSVP [state employees union], Lebe [teachers' union]

Source: Berner Zeitung, 27 November 2004. (I am grateful to Stefan Wyler who provided me with the official recommendations)

a Source: Party homepage

the responses of individual voters-we can consider the results of 389 municipalities (see Table 3). Based on this, I argue that the intransitive result at the cantonal level arises from an aggregation of fully transitive preference orders at the municipal level.

There are six transitive ways in which the questions might be answered. ${ }^{5}$ The preferences of political parties and associations were expressed only in two of them. Because of this, it seems prudent to assume that these options were chosen by the largest part of the electorate. The recommendations of the left-wing and of the right wing parties and associations were exact complements of each other. With this in mind, it follows that a pair of voters, in which one is voting according to the left-wing, and the other according to the right-wing parties, will raise the yes- and no-vote for each option by the same number, but do not affect the overall result. A look at the aggregated results from the 389 municipalities shows that most aggregate voting results correspond either to the left-wing or the right-wing recommendations. Hence, in most municipalities either the left-wing or the right-wing voters outnumbered the other bloc, whereas voters with different voting patterns were smaller in number (or cast opposite votes that cancelled each other out).

However, there were four other possible transitive and several intransitive rank-orders in play for the vote. There are certain combinations of other transitive rank-orders, that, jointly with one of the two dominant voting patterns, might lead to intransitive majority cycles. If in a municipality the number of voters who follow the recommendation of the left-wing and of the right-wing parties is similar, then most of these votes are cancelled out, and then even a few votes that are expressed for one of the four other transitive or for an intransitive preference order might become decisive at the municipal level.

Preferences for two transitive patterns, which plausibly might have attracted a few votes, can, jointly with votes for the two recommendations of the political parties and associations, result in a majority cycle. The order SQ $>\mathrm{VV}>\mathrm{GR}$ reflects voters who clearly favor automatic salary increments over any form of performance-based system. The order VV $>\mathrm{GR}>\mathrm{SQ}$ would be the rational choice of voters who are located between VV and GR and closer to VV than to GR. These are voters who would favor salary increments based on performance rather than automation, but who simultaneously agree that a compromise is better than an extreme solution. Both rank-orders are plausible and rational. Jointly with the rank-order that was recommended by the right-wing parties and business associations, GR $>\mathrm{SQ}>\mathrm{VV}$, they result in the Condorcet cycle, which reflects the overall outcome of the referendum.

${ }^{5}$ Not considering seven additional combinations, where two or three options are ranked equally. 
Table 3 Results by municipalities, by municipalities with the same preference order. Source: Chancellery of the canton

\begin{tabular}{|c|c|c|c|c|c|c|c|c|}
\hline \multirow[b]{2}{*}{$\begin{array}{l}\text { Municipalities of } \\
\text { type... }\end{array}$} & \multirow[b]{2}{*}{$\begin{array}{l}\text { nr of } \\
\text { municip. }\end{array}$} & \multicolumn{7}{|c|}{ Votes (sum) } \\
\hline & & $\begin{array}{l}\text { nr of } \\
\text { voters }\end{array}$ & $\begin{array}{l}\text { GR } \\
\text { yes }\end{array}$ & $\begin{array}{l}\text { GR } \\
\text { no }\end{array}$ & $\begin{array}{l}\text { VV } \\
\text { yes }\end{array}$ & $\begin{array}{l}\text { VV } \\
\text { no }\end{array}$ & $\begin{array}{l}\text { optional } \\
\text { GR }\end{array}$ & $\begin{array}{l}\text { optional } \\
\text { VV }\end{array}$ \\
\hline \multicolumn{9}{|l|}{ Transitive preference orders } \\
\hline $\mathrm{SQ}>\mathrm{VV}>\mathrm{GR}$ & 43 & 17318 & 7708 & 8440 & 7640 & 8447 & 7324 & 8344 \\
\hline $\mathrm{SQ}>\mathrm{VV}=\mathrm{GR}$ & 2 & 147 & 57 & 76 & 66 & 71 & 63 & 63 \\
\hline $\mathrm{SQ}>\mathrm{GR}>\mathrm{VV}$ & 17 & 3926 & 1782 & 1903 & 1568 & 2105 & 1799 & 1710 \\
\hline $\mathrm{SQ}=\mathrm{VV}>\mathrm{GR}$ & 3 & 446 & 195 & 220 & 205 & 205 & 186 & 226 \\
\hline $\mathrm{VV}>\mathrm{SQ}>\mathrm{GR}$ & 80 & 76817 & 34160 & 37824 & 40317 & 31470 & 30578 & 39953 \\
\hline $\mathrm{SQ}=\mathrm{GR}>\mathrm{VV}$ & 2 & 32 & 16 & 16 & 5 & 22 & 17 & 11 \\
\hline $\mathrm{SQ}=\mathrm{GR}=\mathrm{VV}$ & 1 & 14 & 7 & 7 & 6 & 6 & 7 & 7 \\
\hline $\mathrm{VV}>\mathrm{SQ}=\mathrm{GR}$ & 4 & 795 & 377 & 377 & 397 & 354 & 340 & 407 \\
\hline $\mathrm{GR}>\mathrm{SQ}>\mathrm{VV}$ & 179 & 82659 & 44184 & 34045 & 33631 & 43567 & 41631 & 34742 \\
\hline $\mathrm{GR}>\mathrm{SQ}=\mathrm{VV}$ & 2 & 126 & 66 & 54 & 57 & 57 & 60 & 58 \\
\hline $\mathrm{VV}>\mathrm{GR}>\mathrm{SQ}$ & 12 & 17511 & 8527 & 7939 & 8285 & 8077 & 7731 & 8411 \\
\hline $\mathrm{VV}=\mathrm{GR}>\mathrm{SQ}$ & 1 & 45 & 24 & 18 & 23 & 21 & 22 & 22 \\
\hline $\mathrm{GR}>\mathrm{VV}>\mathrm{SQ}$ & 8 & 1436 & 765 & 583 & 694 & 624 & 727 & 623 \\
\hline \multicolumn{8}{|l|}{ municipalities } & 94577 \\
\hline \multicolumn{9}{|c|}{ Intransitive preference orders $\mathrm{VV}>\mathrm{SQ}>\mathrm{GR}>\mathrm{VV}$} \\
\hline $\mathrm{VV}>\mathrm{SQ}>\mathrm{GR}>\mathrm{SQ}$ & 1 & 2394 & 1120 & 1182 & 1212 & 1065 & 1225 & 1031 \\
\hline $\mathrm{VV}>\mathrm{SQ}=\mathrm{GR}>\mathrm{VV}$ & 1 & 78 & 39 & 39 & 42 & 32 & 39 & 30 \\
\hline $\begin{array}{l}\text { Sum for intransitive } \\
\text { municipalities, first type }\end{array}$ & 2 & 2472 & 1159 & 1221 & 1254 & 1097 & 1264 & 1061 \\
\hline \multicolumn{9}{|c|}{ Intransitive preference orders GR $>\mathrm{SQ}>\mathrm{VV}>\mathrm{GR}$} \\
\hline $\mathrm{GR}>\mathrm{SQ}>\mathrm{VV}>\mathrm{GR}$ & 23 & 19728 & 9670 & 9058 & 9019 & 9597 & 8823 & 9390 \\
\hline $\mathrm{GR}=\mathrm{SQ}>\mathrm{VV}>\mathrm{GR}$ & 3 & 786 & 364 & 364 & 342 & 368 & 335 & 353 \\
\hline $\mathrm{GR}>\mathrm{SQ}>\mathrm{VV}=\mathrm{GR}$ & 5 & 1337 & 672 & 586 & 566 & 675 & 608 & 608 \\
\hline $\mathrm{GR}>\mathrm{SQ}=\mathrm{VV}>\mathrm{GR}$ & 2 & 163 & 79 & 65 & 69 & 69 & 71 & 74 \\
\hline $\begin{array}{l}\text { Sum for intransitive municipalities, } \\
\text { second type }\end{array}$ & 33 & 22014 & 10785 & 10073 & 9996 & 10709 & 9837 & 10425 \\
\hline
\end{tabular}

It is plausible that a substantial part of the vote was divided equally between both options that were recommended by the parties and associations, GR $>\mathrm{SQ}>\mathrm{VV}$ or VV $>\mathrm{SQ}>\mathrm{GR}$; this would constitute roughly 100,000 votes for each of both rank orders. A few thousand additional votes might have been cast according to the recommendation of the right-wing parties (more than have been cast in the sense of the left-wing coalition), and for the two rational and transitive options $\mathrm{SQ}>\mathrm{VV}>\mathrm{GR}$ and $\mathrm{VV}>\mathrm{GR}>\mathrm{SQ}$. If none of these three options counts more than the sum of the two others overall, then a Condorcet cycle emerges. Looking at the big picture, this perfectly explains the overall outcome here.

Clearly, the two other transitive options lacked a major number of votes (and, out of 200,000 remaining voters, several might have cast an intransitive vote). Voters who favored fully flexible salaries above all other alternatives would have most likely ranked the options 
in the order GR $>\mathrm{VV}>\mathrm{SQ}$, if they did not vote strategically. Conversely, those SQ-oriented voters who prefer simple remuneration systems and opposed to any combinations of the two extreme options, would vote SQ $>$ GR $>$ VV. These two preference orders-along with a substantial number of votes for the two rank-orders recommended by the political parties, and the few additional votes supporting the left-wing coalition-might explain the aggregated outcome in the two municipalities with the aggregated intransitive rank order $\mathrm{VV}>\mathrm{SQ}>\mathrm{GR}>\mathrm{SQ}$ and $\mathrm{VV}>\mathrm{SQ}=\mathrm{GR}>\mathrm{VV}$.

While the municipal-level aggregated results do not allow us to identify patterns of individual voting behavior, we can use them to figure out just how municipal results-which are mainly transitive-give rise to a Condorcet cycle at the cantonal level. To do so, I consider the results of the 354 municipalities that demonstrated a transitive rank order; these municipalities make up $89 \%$ of the cantonal electorate. The sum of the results of these municipalities, one notes, is no longer transitive. While many votes cancel each other out, the sum still results in a Condorcet cycle of the order GR $>$ SQ $>$ VV $>$ GR, with an excess of 2000 to 6000 decisive votes for each referendum question. This corresponds with the final result of the referendum. The outcome is not affected by the 35 municipalities ( $11 \%$ of the electorate) that demonstrate an intransitive aggregated preference order. The municipalities with the rank order GR $>\mathrm{SQ}>\mathrm{VV}>\mathrm{GR}$ (intransitive municipalities of second type), add some 600-700 decisive votes that are in line with the overall result (again, after subtracting the votes that cancel each other out). The municipalities with the inverse intransitive preference order VV $>$ SQ $>$ GR $>$ VV change the overall result only slightly. There are only some 60-200 votes that create a majority cycle in the opposite direction, much fewer than from municipalities with the majority cycle GR $>\mathrm{SQ}>\mathrm{VV}>\mathrm{GR}$. Thus, the results from the municipalities with intransitive preference orders reinforce the Condorcet paradox overall. And to a greater extent, it is clear that most of the decisive votes for the majority cycle come from the 354 municipalities with fully transitive voting results.

This analysis does not rule out the possibility that some voters may indeed have been confused in the vote, and could have filled in their ballot in an intransitive way. However, there is little reason to believe that these confused voters would all have chosen the same intransitive choice. If voters were confused, it is very likely that some among them would have submitted intransitive preference orders, but in different permutations, so that the ballots of different intransitive voters would have cancelled each other out.

We should consider the fact that, in decisions that consist of several questions, it is possible for a winning combination to emerge that has not been voted for by a single voter. The voting procedure in Bern requires voters to answer three distinct, but interconnected questions. If a decision is linked to multiple questions, then with each additional question, the likelihood increases that the overall decision will be one that has been supported by very few, or even no voters at all. This phenomenon is described in detail in the 'paradox of multiple elections' (Brams et al. 1997, 1998). ${ }^{6}$

\section{Sincere or strategic preference orders?}

The parties' voting recommendations, along with other plausible transitive preference orders, can explain the intransitive outcome of the referendum vote. Even if a few voters might

\footnotetext{
${ }^{6}$ A typical example of this is a reform package that consists of several partial reforms, all of which are supported by a-different—-majority of voters. While each of these reforms attains majority support, the package might not win against the status quo (see Andrews 2002 for examples). In such situations, a Condorcet cycle emerges.
} 
have cast ballots with a circular preference order, the overall outcome can be explained by a combination of transitive preferences. At the municipal level, the results show that the results of all municipalities with transitive aggregated preferences add up to an overall intransitive result for the referendum.

However, considering the content of the proposals, one might doubt whether a cyclic majority could possibly result from sincere voting. As Fig. 1 suggests, the status quo and the parliamentary amendment represent the two extreme options, whereas the people's amendment is a compromise of the two-located exactly halfway between the status quo and the parliamentary reform project. The main conflict dimension exists between partisans of performance-based wage increases in the public sector (GR), and automatic standard wage increases (SQ). Against this background, the voting recommendation of the right-wing parliamentary majority might astonish an uninitiated observer. According to their recommendation, the parliamentary amendment (GR) is the most preferred option. One might expect that a moderate reform-proposed by the left-wing parties (VV), and going exactly half as far as the parliamentary amendment-might convince the same actors more strongly than the status quo. However, this was not the case.

Apart from the discussion over performance-based versus automatic wage increases, which dominated the public opinion-formation, there might be a second, hidden dimension that mattered to the voters. It is possible that certain voters may have evaluated clear-cut solutions as superior to mixed incentives. Going half way in each direction could have be seen as creating an incentive structure that combined the advantages of each extreme solution-or it could have been seen as combining the two systems' weakneesses. ${ }^{7}$ Alternately, for procedural reasons, the people's proposal might have lacked the support that the parliamentary proposal attracted, because it did not pass the usual lawmaking procedure.

It appears more plausible, however, that the right-wing parties' and associations' sincere preferences were $\mathrm{GR}>\mathrm{VV}>\mathrm{SQ}$, and that their voting recommendation $\mathrm{GR}>\mathrm{SQ}>\mathrm{VV}$ was strategic. On the one hand-and as the referendum result have borne out—strategic voting would serve as one option for creating a majority cycle, so that their first preference, $\mathrm{GR}$, might eventually emerge as the winner. If only a few thousand voters more would have voted for the preference order GR $>\mathrm{VV}>\mathrm{SQ}$, instead of following the possibly strategic recommendation of the right-wing parties, the majority cycle would not have occurred, and the compromise option VV would have been a Condorcet winner. Hence, if the right-wing parties' sincere preference was GR $>\mathrm{VV}>\mathrm{SQ}$, a voting recommendation GR $>\mathrm{SQ}>\mathrm{VV}$ was certainly the right choice to help their first preference GR emerge as the winner. On the other hand, the parliamentary majority did not use arguments that might have indicated a second dimension in their recommendation, and that might have made the preference order GR $>$ SQ $>$ VV plausible. They explained their rejection of the people's amendment VV in the official voters' information booklet (Grosser Rat des Kantons Bern 2004: 6), by stating that any automatism in the increment of salaries that was not linked to performance was unwanted. However, this argument would similarly - and perhaps even more intenselyplay against the SQ. Perhaps the mere rejection of the people's proposal made it easier to communicate why the electorate should favor the parliamentary proposal over a compromise solution. ${ }^{8}$ In short, it appears plausible that the right-wing parties' recommendation was

\footnotetext{
${ }^{7}$ Shafir et al. (1989) make a similar argument for individuals who are asked to choose between two extreme benefit options and a compromise. (I am grateful to an anonymous reviewer for making this point.) In the present example, where most voters do not preside over their own wages, but rather over the wages of others, even more complex considerations are possible.

${ }^{8}$ The rejection of the people's amendment has made it possible to draw a black-and-white picture of the subjects of the vote, in which the parliamentary proposal was recognized as desirable, the people's proposal as
} 
primarily strategically driven, in order to allow their first preference GR to win the vote. In this case, it is likely that only a few voters voiced a sincere preference order GR $>$ SQ $>$ VV, while most of the other voters of this group were casting a strategic vote. If only a small part of these voters had voted sincerely, the Condorcet paradox would not have emerged.

\section{Conclusions}

Despite the prominence of the majority cycles paradox in the public choice literature, their occurrence has rarely been documented (Green and Shapiro 1994: 113). Multi-option referendums are practiced infrequently, and parliaments and committees usually apply multioption decision procedures. As stated above, these do not reveal a full ordering of preferences.

This paper contributes to the empirical literature on majority cycles, documenting a new referendum type that has been introduced recently in several Swiss cantons-the referendum-with-people's-amendment. It allows for multi-option referendums, and, because it relies on a full pair-wise comparison of these options on the ballot, it makes majority cycles directly visible. Interestingly enough, the result of one of the first cases of a referendumwith-people's-amendment was a majority cycle.

As I have suggested in my analysis, the Condorcet cycle that occurred in the Swiss canton of Bern most likely resulted from a strategic voting recommendation, deployed by a large number of the political parties and associations. The arguments used in the referendum campaign reveal that the discussion mainly was oriented along one dimension, and the voting recommendation of one part of the political spectrum appears to be strategic. This may explain why the majority cycle emerged, despite the dominance of a single dimension in the discussion. If this is the case, then out of three options-which included an extreme reform (GR), a less extreme reform (VV), and the status quo (SQ) - the middle option (VV) would probably have been the clear Condorcet winner. Only the strategic recommendation of the reform-prone parties (GR $>\mathrm{SQ}>\mathrm{VV}$, instead of their plausibly sincere preference $\mathrm{GR}>\mathrm{VV}>\mathrm{SQ}$ ) enabled their favored option, GR, to win.

This strategic pro-reform vote was made possible only by the reform-friendly nature of the applied voting procedure. In different institutional frameworks, the status quo typically emerges as the beneficiary of majority cycles. But the constructive referendum rule that has newly been applied in several Swiss cantons favors the acceptance of one of the reform proposals in these cases. In the case of the law on the public employees' remuneration, this allowed the most far-reaching reform project to win, probably due to the strategic voting of the solicitors of this reform.

Acknowledgements I am grateful to Simon Hug and Hannu Nurmi and two anonymous reviewers who provided helpful comments on this paper.

\section{References}

Andrews, J. T. (2002). Majorities fail. The Russian Parliament, 1990-1993. Cambridge: Cambridge University Press.

undesirable. Such a message might be easier to communicate to the voters. Supporting both reform proposals, but one more than the other, might be more difficult to communicate and thus be less well understood and followed by the voters. 
Black, D. (1958). The theory of committees and elections. Boston: Kluwer.

Brams, S. J., Kilgour, D. M., \& Zwicker, W. S. (1997). Voting on referenda: the separability problem and possible solutions. Electoral Studies, 16(3), 359-377.

Brams, S. J., Kilgour, D. M., \& Zwicker, W. S. (1998). The paradox of multiple elections. Social Choice and Welfare, 15, 211-236.

Chamberlin, J. R., Cohen, J. L., \& Coombs, C. H. (1984). Social choice observed: five presidential elections of the American Psychological Association. Journal of Politics, 46(2), 479-502.

Feld, S. L., \& Grofman, B. (1988). Ideological consistency as a collective phenomenon. American Political Science Review, 82(3), 773-788.

Feld, S. L., \& Grofman, B. (1992). Who's afraid of the big bad cycle? Evidence from 36 elections. Journal of Theoretical Politics, 4(2), 231-237.

Gaubatz, K. T. (1995). Intervention and intransitivity: Public opinion, social choice, and the use of military force abroad. World Politics, 47, 534-554.

Gehrlein, W. V. (2006). Condorcet's paradox. Berlin: Springer.

Gehrlein, W. V., \& Fishburn, P. C. (1976). Condorcet paradox and anonymous preference profiles. Public Choice, 26, 1-18.

Green, D. P., \& Shapiro, I. (1994). Pathologies of rational choice theory. A critique of applications in political science. New Haven: Yale University Press.

Grofman, B. (2004). Reflections on public choice. Public Choice, 118(1), 31-51.

Grosser Rat des Kantons Bern (2004). 28. November 2004, Kantonale Volksabstimmung, Botschaft des Grossen Rates des Kantons Bern. Bern: Kanton Bern.

Higley, J., \& McAllister, I. (2002). Elite division and voter confusion: Australia's republic referendum in 1999. European Journal of Political Research, 41, 845-861.

Jenkins, J. A., \& Munger, M. C. (2003). Investigating the incidence of killer amendments in congress. Journal of Politics, 65, 498-517.

Jones, B., Radcliff, B., Taber, C., \& Timpone, R. (1995). Condorcet winners an the paradox of voting: probability calculations for weak preference orders. American Political Science Review, 89(1), 845-861.

Kurrild-Klitgaard, P. (2001). An empirical example of the Condorcet paradox of voting in a large electorate. Public Choice 107(1-2), 135-145.

Kurrild-Klitgaard, P. (2008). Voting paradoxes under proportional representation: evidence from eight Danish elections. Scandinavian Political Studies, 31(3), 242-267.

Lagerspetz, E. (1997). Social choice in the real World II: cyclical preferences and strategic voting in the Finnish presidential elections. Scandinavian Political Studies, 20(1), 53-67.

Linder, W. (1999). Schweizerische Demokratie. Institutionen, Prozesse, Perspektiven. Bern: Haupt.

Lutz, G., \& Strohmann, D. (1998). Wahl- und Abstimmungsrecht in den Kantonen. Bern: Haupt.

Mackie, G. (2003). Democracy defended. Cambridge: Cambridge University Press.

Nurmi, H. (1998). Voting paradoxes and referenda. Social Choice and Welfare, 15, 333-350.

Nurmi, H. (1999). Voting paradoxes and how to deal with them. Berlin: Springer.

Regenwetter, M., Grofman, B., Marley, A. A. J., \& Tsetlin, I. (2006). Behavioral social choice. Probabilistic models, statistical inference, and applications. Cambridge: Cambridge University Press.

Riker, W. H. (1958). The paradox of voting and congressional rules for voting on amendments. American Political Science Review, 52(2), 349-366.

Riker, W. H. (1982). Liberalism against populism. San Francisco: Freeman.

Riker, W. H. (1986). The art of political manipulation. New Haven: Yale University Press.

Saari, D. G. (2001). Decisions and elections. Explaining the unexpected. Cambridge: Cambridge University Press.

Sen, A. K. (1970). Collective choice and social welfare. San Francisco: Holden-Day.

Senti, M. (1998). Strategisches Abstimmungsverhalten in legislativen Entscheidungsprozessen: Ein Fallbeispiel. Swiss Political Science Review, 4(2), 1-24.

Shafir, E. B., Osherson, D. N., \& Smith, E. E. (1989). An advantage model of choice. Journal of Behavioral Decision Making, 2, 1-23.

Shepsle, K. A. (1979). Institutional arrangements and equilibrium in multidimensional voting models. American Journal of Political Science, 23, 27-60.

Tullock, G. (1981). Why so much stability? Public Choice, 37(2), 189-202.

Van Deemen, A. (1999). The probability of the paradox of voting for weak preference orderings. Social Choice and Welfare, 16(2), 171-182.

Van Deemen, A., \& Vergunst, N. P. (1998). Empirical evidence of paradoxes of voting in Dutch elections. Public Choice, 97(3), 475-490.

Wyler, S. (2004). Ein Zufallsresultat. Der Bund, 29 November, 37.

Wyler, S. (2005). Das Volk und der Volksvorschlag. Der Bund, 23 May, 25. 